\title{
SNS RFQ Cooling Water Chemical Treatment
}

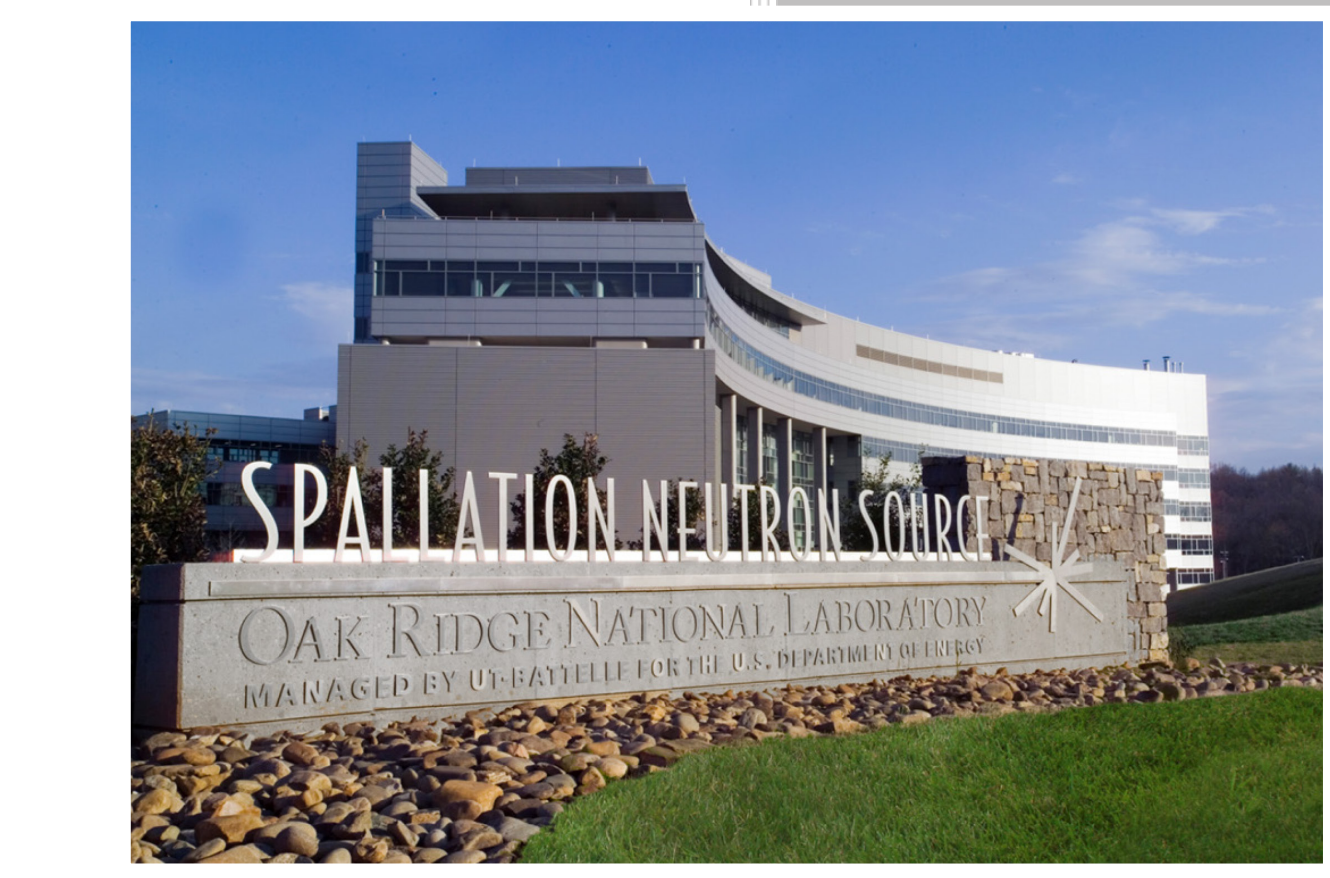

Karoly Magda

February 2017

Approved for public release. Distribution is unlimited. 


\title{
DOCUMENT AVAILABILITY
}

Reports produced after January 1, 1996, are generally available free via US Department of Energy (DOE) SciTech Connect.

Website http://www.osti.gov/scitech/

Reports produced before January 1, 1996, may be purchased by members of the public from the following source:

\author{
National Technical Information Service \\ 5285 Port Royal Road \\ Springfield, VA 22161 \\ Telephone 703-605-6000 (1-800-553-6847) \\ TDD 703-487-4639 \\ Fax 703-605-6900 \\ E-mail info@ntis.gov \\ Website http://classic.ntis.gov/
}

Reports are available to DOE employees, DOE contractors, Energy Technology Data Exchange representatives, and International Nuclear Information System representatives from the following source:

Office of Scientific and Technical Information PO Box 62

Oak Ridge, TN 37831

Telephone 865-576-8401

Fax 865-576-5728

E-mail reports@osti.gov

Website http://www.osti.gov/contact.html

This report was prepared as an account of work sponsored by an agency of the United States Government. Neither the United States Government nor any agency thereof, nor any of their employees, makes any warranty, express or implied, or assumes any legal liability or responsibility for the accuracy, completeness, or usefulness of any information, apparatus, product, or process disclosed, or represents that its use would not infringe privately owned rights. Reference herein to any specific commercial product, process, or service by trade name, trademark, manufacturer, or otherwise, does not necessarily constitute or imply its endorsement, recommendation, or favoring by the United States Government or any agency thereof. The views and opinions of authors expressed herein do not necessarily state or reflect those of the United States Government or any agency thereof. 
ORNL/TM-2017/10

SNS-RAD-MS-TR-0011, R00

Research Accelerator Division

\title{
SNS RFQ COOLING WATER \\ CHEMICAL TREATMENT
}

\author{
Karoly Magda
}

Date Published: February 2017

Prepared by

OAK RIDGE NATIONAL LABORATORY

Oak Ridge, TN 37831-6283

managed by

UT-BATTELLE, LLC

for the

US DEPARTMENT OF ENERGY

under contract DE-AC05-00OR22725 



\section{CONTENTS}

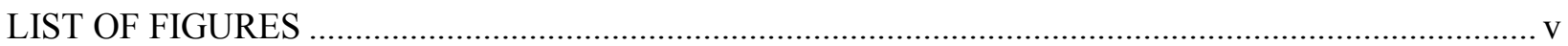

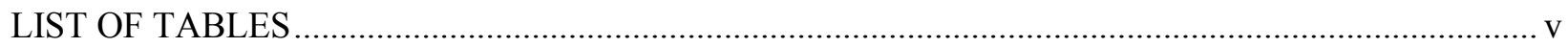

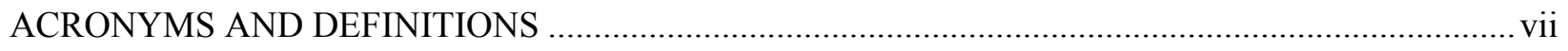

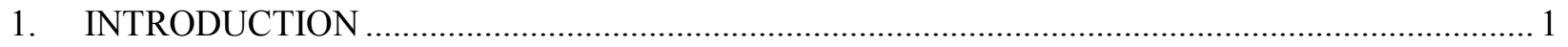

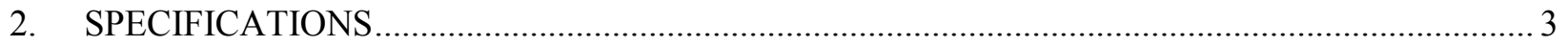

3. HISTORY OF RFQ CHILLER WATER CHEMISTRY ….................................................... 3

3.1 INITIAL CHEMICAL TREATMENT OF RFQ CHILLER WATER AT BERKELEY ........... 3

3.2 CHEMICAL TREATMENT OF BERKELEY (FE) RFQ CHILLER WATER AT SNS .......... 4

3.3 CHEMICAL TREATMENT OF SNS (SPARE OR BTF) RFQ CHILLER WATER AT RFTF

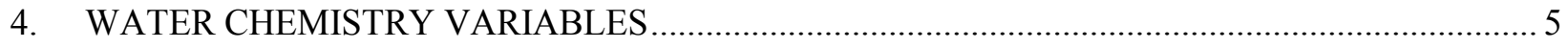

4.1 COOLING PASSAGE CORROSION RATE VARIABLES ……........................................ 5

4.2 THEORY AND CHARTS ON CORROSION RATE VARIABLES …................................ 5

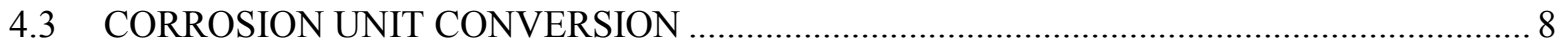

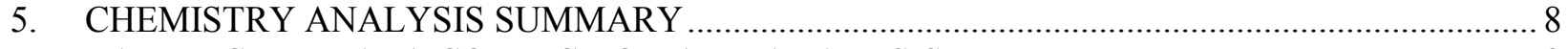

5.1 RECENT DATA COLLECTION AND ANALYSIS ....................................................... 8

5.2 OBSERVATION FROM CHEMICAL ANALYSIS DATA CHARTS IN APPENDIX A ....... 8

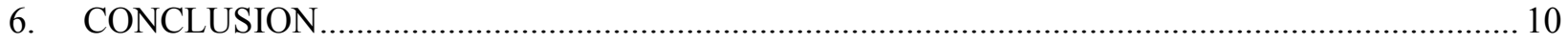

6.1 OBSERVATIONS FROM FIGURE 8, CORROSION RATE AT VARIOUS

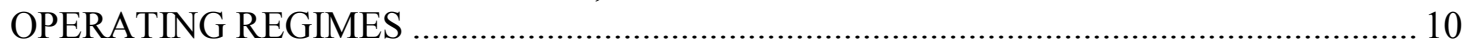

6.2 OBSERVATIONS FROM SNS RFQ PENETRATION RATE CALCULATION.................. 10

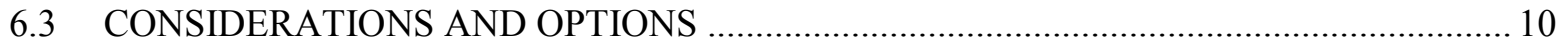

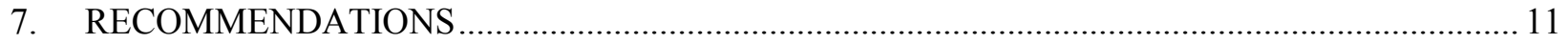

7.1 RECOMMENDATION FOR BERKELEY RFQ COOLING WATER CHEMISTRY ........... 11

7.2 RECOMMENDATION FOR SNS (SPARE OR BTF) RFQ COOLING WATER CHEMISTRY

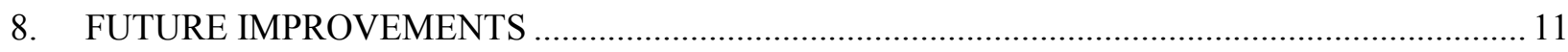

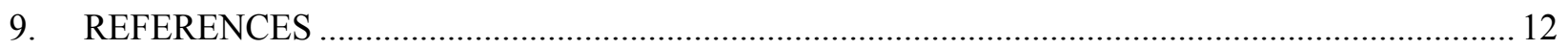

APPENDIX A. CHEMICAL ANALYSIS DATA CHARTS FROM NOVEMBER 2014 TO MAY

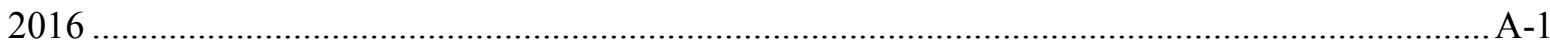

APPENDIX B. CALCULATION OF COPPER PENETRATION RATE ........................................ B-1

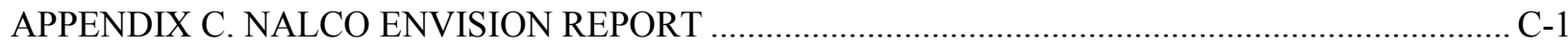





\section{LIST OF FIGURES}

Figure 1. SNS accelerator layout on the Experimental Physics and Industrial Control System

(EPICS) main screen. 1

Figure 2. SNS accelerator front end with the main components................................................. 2

Figure 3. Berkeley RFQ cross section with cooling channels ........................................................... 3

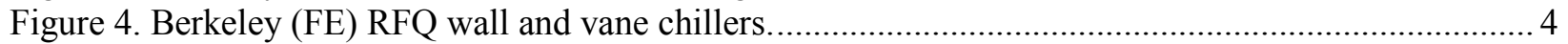

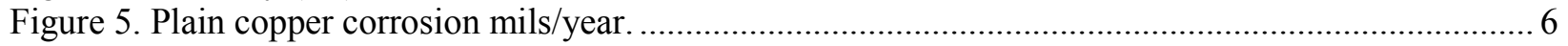

Figure 6. Corrosion rate as a function of oxygen concentration. ........................................................ 6

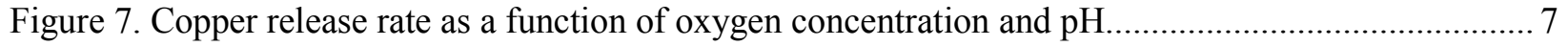

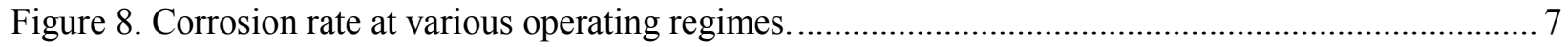

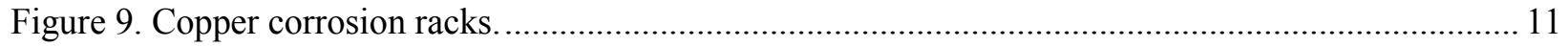

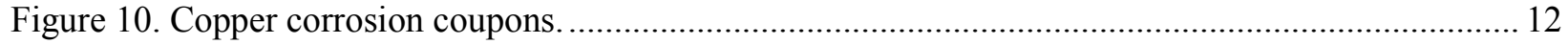

\section{LIST OF TABLES}

Table 1. Example of a weekly water treatment analysis report ….......................................................... 5

Table 2. Berkeley (FE) RFQ chemistry data (averaged since November 2014)..................................... 9

Table 3. SNS (spare) RFQ chemistry data (averaged since August 2015) .............................................. 9 



\section{ACRONYMS AND DEFINITIONS}

$\begin{array}{ll}\begin{array}{l}\text { Berkeley } \\ \text { Berkeley RFQ }\end{array} & \begin{array}{l}\text { Lawrence Berkeley National Laboratory } \\ \text { Operates at the SNS accelerator front end }\end{array} \\ \text { BTF } & \text { Beam Test Facility } \\ \text { cfu } & \text { colony forming unit-refers to bacteria } \\ \text { EPICS } & \text { Experimental Physics and Industrial Control System } \\ \text { EPRI } & \text { Electric Power Research Institute } \\ \text { FE } & \text { front end } \\ \text { ft/s } & \text { foot per second-fluid velocity } \\ \text { MEBT } & \text { medium-energy beam transport } \\ \text { mils/year } & \text { mils per year-copper release rate of cooling channels } \\ \text { ORNL } & \text { Oak Ridge National Laboratory } \\ \text { pH } & \text { alkalinity-pH }<7=\text { acidic; } \mathrm{pH}>7=\text { alkaline; } \mathrm{pH}=7=\text { neutral } \\ \text { ppb } & \text { parts per billion } \\ \text { ppm } & \text { parts per million } \\ \text { RFQ } & \text { radio-frequency quadrupole } \\ \text { RFTF } & \text { Radio-Frequency Test Facility } \\ \text { SNS } & \text { Spallation Neutron Source } \\ \text { SNS RFQ } & \text { SNS radio-frequency quadrupole } \\ \text { TTppm } & \text { tolyltriazole parts per million }\end{array}$





\section{INTRODUCTION}

The Berkeley radio-frequency quadrupole (RFQ) is installed at the front end of the accelerator and provides the initial acceleration and bunching to the negatively charged hydrogen ions, $\mathrm{H}^{(-2)}$, that make up the beam. For RFQs to work properly, their temperature must be controlled by cooling water.

The Berkeley RFQ, along with the front-end (FE) technical equipment, was constructed, tested, and delivered to SNS by Lawrence Berkeley National Laboratory (Berkeley). The priority was to install the equipment and demonstrate that the accelerator would function as designed. The water chemistry definition was not a primary task; therefore, the water chemistry requirements were not defined and documented and went through several changes after startup.

The purpose of this document is to describe the chemical treatment protocol for the cooling water used with the installed RFQ (the Berkeley RFQ) so it can be adopted it for a new RFQ (the SNS RFQ). The SNS RFQ was designed to serve as a spare and was manufactured and delivered in 2015. It is being tested at the SNS Radio-Frequency Test Facility (RFTF) - part of the Beam Test Facility (BTF). When testing is complete, the Berkeley RFQ will be removed and replaced with the SNS RFQ. The SNS accelerator layout and a photo of the front end with the main components are shown in Figures 1 and 2, respectively.

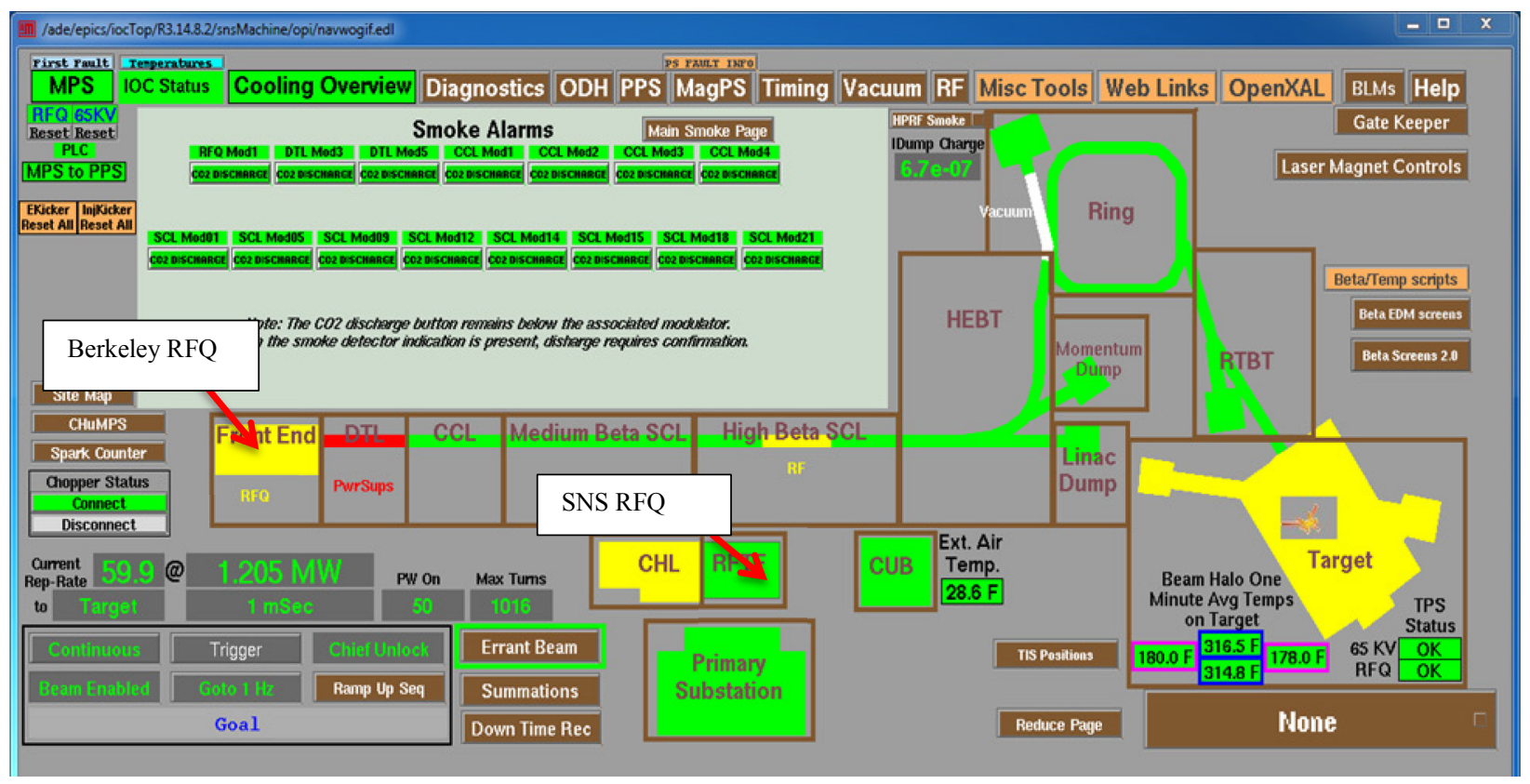

Figure 1. SNS accelerator layout on the Experimental Physics and Industrial Control System (EPICS) main screen. 


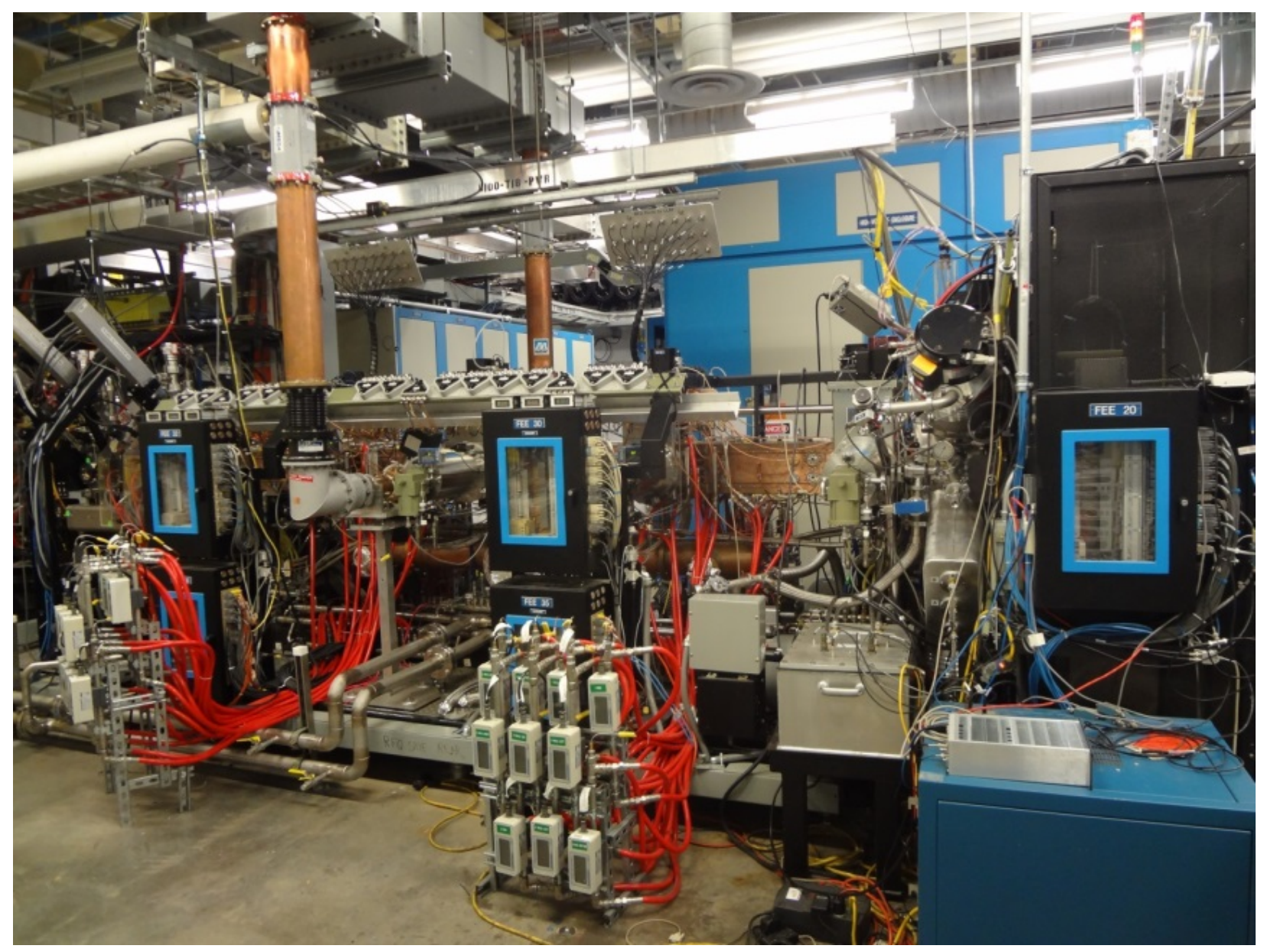

Figure 2. SNS accelerator front end with the main components.

The objective for the water chemistry for both the Berkeley RFQ and the SNS RFQ is to ensure that the RFQ design life is achieved and to protect the cooling water passages and brazed joints from erosion, corrosion, and fouling. Any clogging or leaking of cooling water passages could result in a very long downtime for the accelerator, endangering the science mission continuity. The RFQ cross section with the cooling channels is presented in Figure 3. 

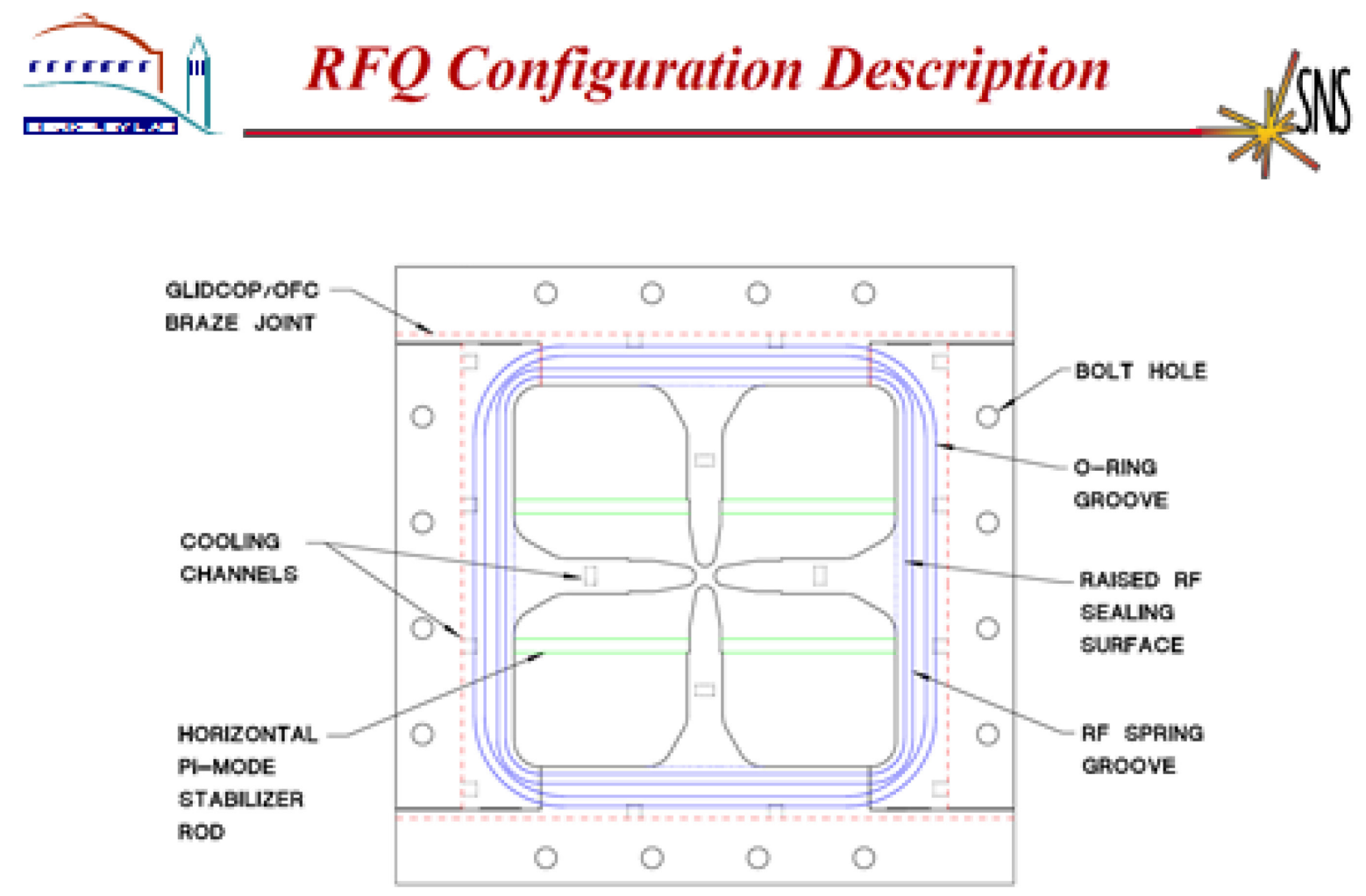

Figure 3. Berkeley RFQ cross section with cooling channels. Image courtesy of Steve Virostek and Matt Hoff, RFQ Modules 2, 3, and 4 Preliminary Design Review. ${ }^{1}$

\section{SPECIFICATIONS}

SNS is adhering to the following specifications to preserve the Berkeley RFQ cooling passages:

- SNS Water Chemistry Specification specifies a copper corrosion limit of 0.5 mil/year. ${ }^{2}$ The copper structure material at SNS is UNS No. C10100, which is low-oxygen copper.

- The limit of cooling water velocity through the passages is specified as $15 \mathrm{ft} / \mathrm{s}$.

\section{HISTORY OF RFQ CHILLER WATER CHEMISTRY}

\subsection{INITIAL CHEMICAL TREATMENT OF RFQ CHILLER WATER AT BERKELEY}

During testing at Berkeley, RFQ cooling was provided by two chillers: one for the RFQ walls and one for the RFQ vanes. The chillers were procured by Berkeley from BV Voltex Thermal Systems in California. The chillers were chosen because of previous experience using them and because of their affordability, flexibility, precise temperature control, and simplicity. The goal of testing was to determine total heat loads and tuning sensitivity, not the optimum cooling fluid. For testing purposes, the Berkeley team chose a cooling fluid of untreated water and low-concentration isopropyl alcohol $(10 \%)$, which was added as a biocide. They left it to the owners of the RFQ (SNS) to decide the cooling fluid type (which could be a 
mix of glycol and water), including the chemical treatment requirements. Figure 4 shows the Berkeley (FE) RFQ chillers.

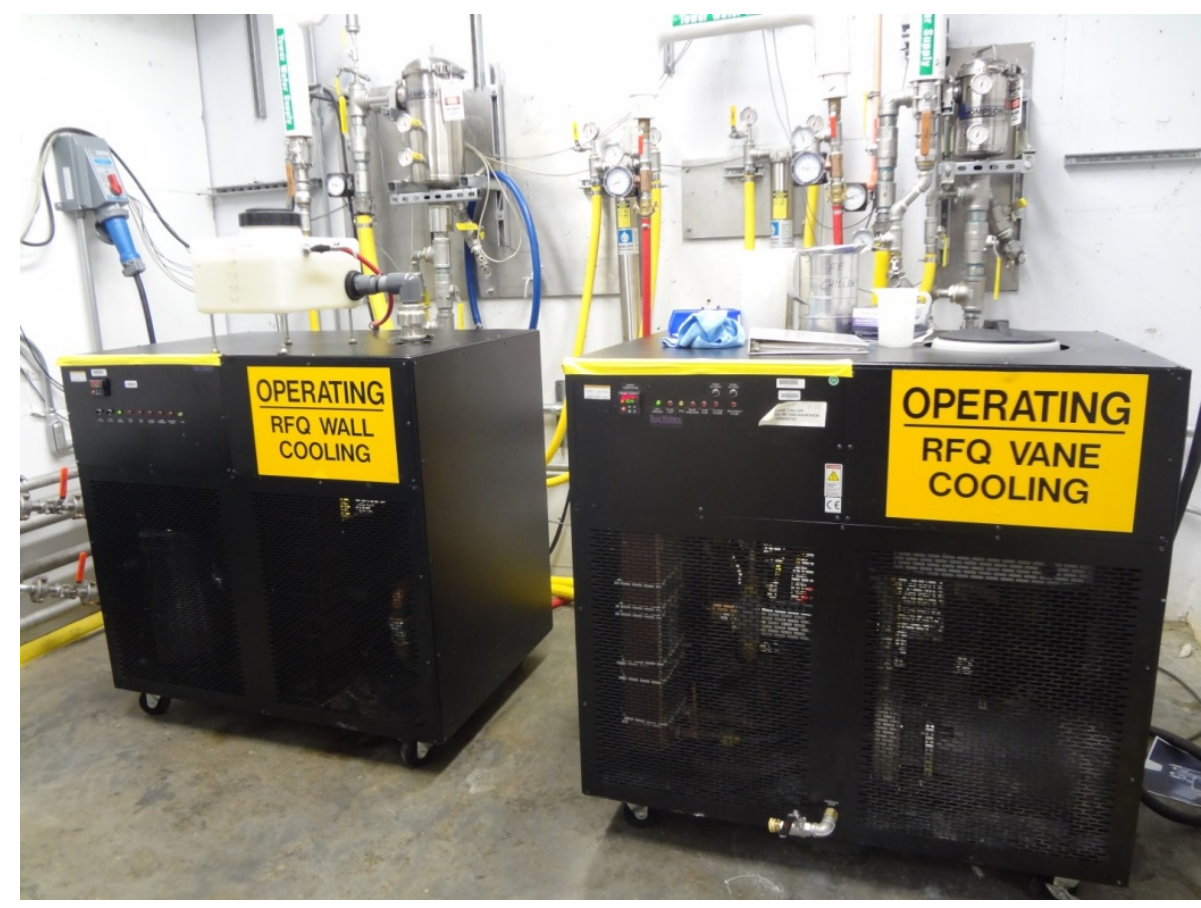

Figure 4. Berkeley (FE) RFQ wall and vane chillers.

\subsection{CHEMICAL TREATMENT OF BERKELEY (FE) RFQ CHILLER WATER AT SNS}

When the Berkeley RFQ with the accompanying chillers was delivered to Oak Ridge National Laboratory (ORNL), SNS Fire Protection staff did not approve the use of a water/alcohol mix as the cooling fluid. The chillers and distribution piping were initially filled with KL-04 DI water, which was not treated in the chiller circuit. After accelerator startup, the RFQ chiller chemistry protocol went through several changes.

Initially, a subcontractor was hired to treat the water for the RFQ chillers. The firm treated the water with two agents:

- The first was a corrosion inhibitor for the protection of yellow metals (copper, brass, etc.) and mild steel.

- The second was an antimicrobial agent.

No sampling or analysis was conducted on a regular basis, and no reports were provided to SNS; therefore, it was not understood how the chemicals impacted the cooling passages. The brass fittings on the medium-energy beam transport (MEBT) structures began to leak, and incorrect chemical dosing of the water was determined to be the cause.

In a self-directed effort SNS staff treated the water in a way similar to the original treatment, with a corrosion inhibitor and an antimicrobial agent, as recommended by the first subcontractor. Still no regular sampling or analysis was conducted.

In recent years another subcontractor was hired for the RFQ cooling water treatment, and the treatment still consists of an antimicrobial agent and a corrosion inhibitor for yellow metals only. Weekly sampling 
and chemical analysis is conducted, and regular reports are provided to SNS. The reports include the values shown in Table 1.

Table 1. Example of a weekly water treatment analysis report

\begin{tabular}{|l|c|c|c|}
\hline \multicolumn{1}{|c|}{ Closed loop wet test } & RFQ vane chiller & RFQ wall chiller & Control ranges \\
\hline Conductivity $(\mu \mathrm{S} / \mathrm{cm})$ & 67.1 & 231 & Record \\
\hline $\mathrm{pH}$ & 7.8 & 7.4 & $7.2-10.5$ \\
\hline Trasar $(\mathrm{ppm})$ & $\mathrm{n} / \mathrm{a}$ & $\mathrm{n} / \mathrm{a}$ & $2000-6000$ \\
\hline $\mathrm{MoO}_{4}$ & $\mathrm{n} / \mathrm{a}$ & $\mathrm{n} / \mathrm{a}$ & $75-150$ \\
\hline Tolyltriazole $(\mathrm{TTppm})$ & 7.3 & 7.3 & $3-6.4$ \\
\hline Copper $(\mathrm{ppm})$ & 0.12 & 0.13 & $<0.2$ \\
\hline Iron $\left(\mathrm{Fe}_{2}\right)$ & 0 & 0 & $<0.5$ \\
\hline Aerobic bacteria $(\mathrm{cfu})$ & 10 & 0 & $<100$ \\
\hline Anaerobic bacteria $(\mathrm{cfu})$ & 0 & 0 & 0 \\
\hline
\end{tabular}

\subsection{CHEMICAL TREATMENT OF SNS (SPARE OR BTF) RFQ CHILLER WATER AT RFTF}

The SNS RFQ was designed and manufactured by RI Research Instruments in Germany and was delivered to SNS in fall 2014. Installation at the Radio-Frequency Test Facility (RFTF) Annex was completed in spring 2015, and the tests were started soon after that. The vane and wall chillers were ordered from the same manufacturer as for the Berkeley RFQ (BV Thermal in California), and were installed in the RFTF pump room. No regular chemical analysis or water treatment was done before August 2015, and no complete chemical treatment has yet been established, only biocide treatment.

\section{WATER CHEMISTRY VARIABLES}

\subsection{COOLING PASSAGE CORROSION RATE VARIABLES}

The cooling passage corrosion rate is a function of several variables:

- Flow velocity

- Dissolved oxygen concentration

- Low oxygen region: $\mathrm{ppb}_{2}<30$

○ Mid region: $30<\mathrm{ppb}_{2}<1000$

$\circ \quad$ Air saturated: $p p b \mathrm{O}_{2}>1000$

- $\mathrm{pH}$

○ Neutral: 7

○ Acidic: $<7$

○ Basic: $>7$

\subsection{THEORY AND CHARTS ON CORROSION RATE VARIABLES}

Figures 5-8 show the copper corrosion rate as a function of fluid velocity in the cooling passages, oxygen concentration in water, and $\mathrm{pH}$. Figure 8 presents the corrosion rate at various operating regimes. Figures 6, 7, and 8 are also described in "Cooling Water Systems Serving Copper Technical Components." 3 
The three curves in Figure 5 show the plain copper corrosion rate as a function of oxygen concentration for three different fluid velocities. It can be noted that the copper corrosion rate is highest around 100-300 $\mathrm{ppb}$ and that the area of 50-600 ppb should be avoided. The copper corrosion is also higher when the fluid velocity is higher (upper curve).

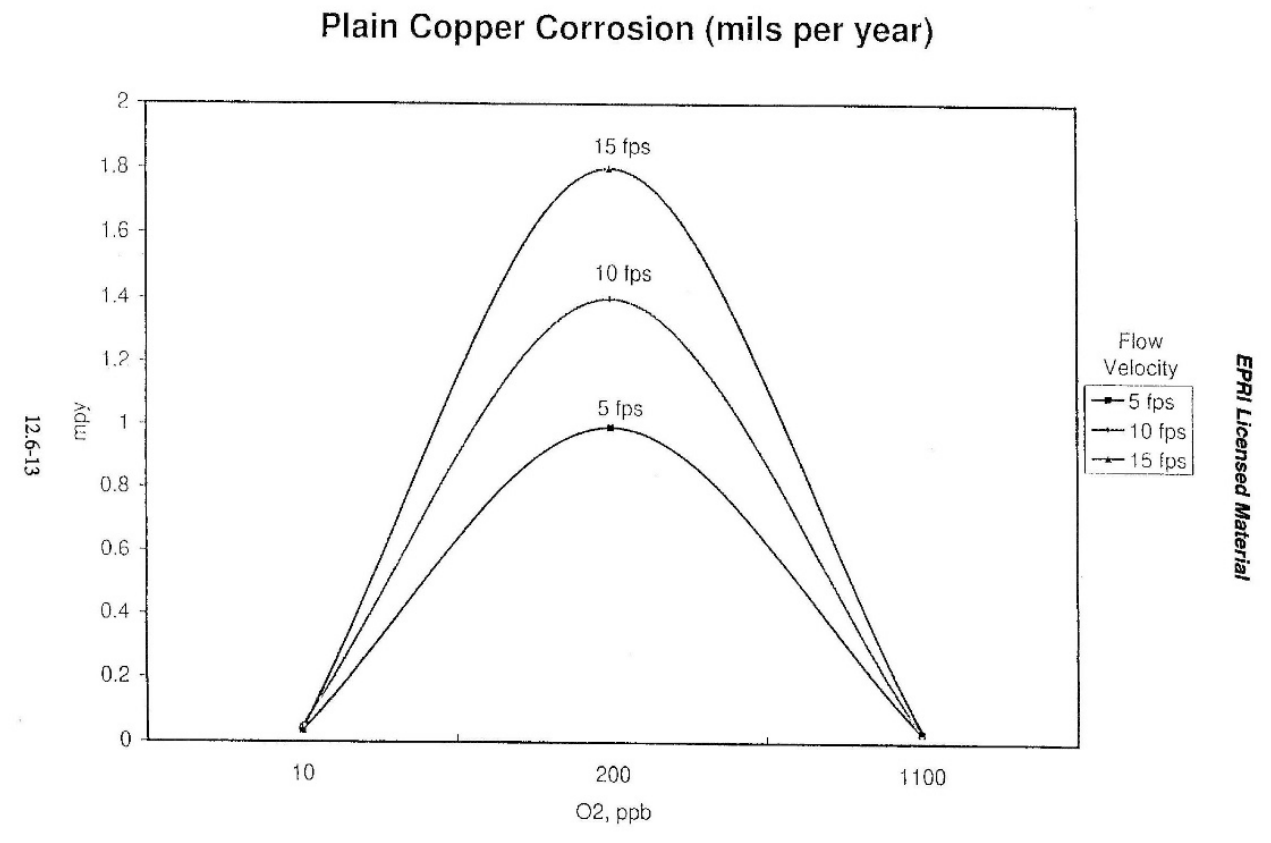

Figure 5. Plain copper corrosion mils/year. Source: Primer on Maintaining the Integrity of Water-Cooled Generator Stator Windings, EPRI TR-105504. ${ }^{4}$

As observed by P. H. Effertz and W. Fichte, Figure 6 shows that the corrosion rate is a function of oxygen concentration in the cooling water.

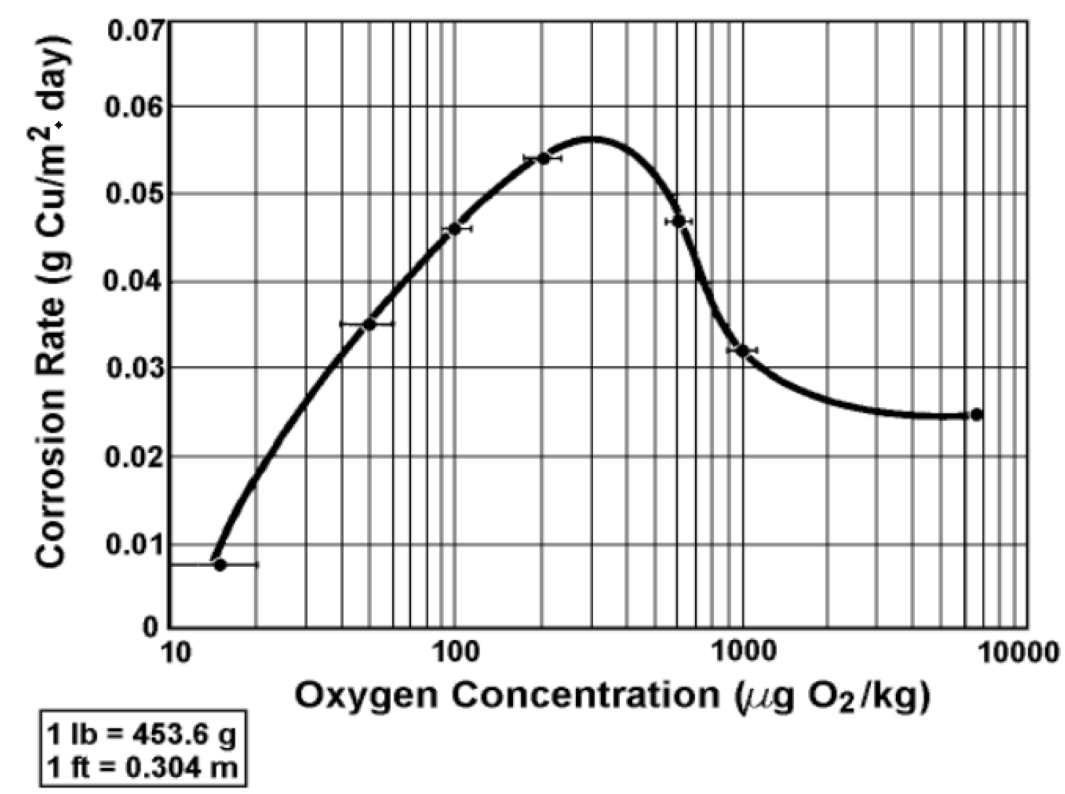

Figure 6. Corrosion rate as a function of oxygen concentration. Source: P. H. Effertz and W. Fichte, Influencing Copper Corrosion in High Purity Water. ${ }^{5}$ 
From Figure 7, it can be concluded that the corrosion rate is highest when the oxygen concentration is about 50-600 $\mathrm{ppb} \mathrm{O}_{2}$ and that the corrosion rate decreases when the water is mildly alkaline (shown by the two bottom curves for $\mathrm{pH}=8$ and $\mathrm{pH}=8.5$ ). It is recommended that the oxygen concentration be kept below ppb $\mathrm{O}_{2}<30$ or in the higher region of $\mathrm{ppb}_{2}>1000$.

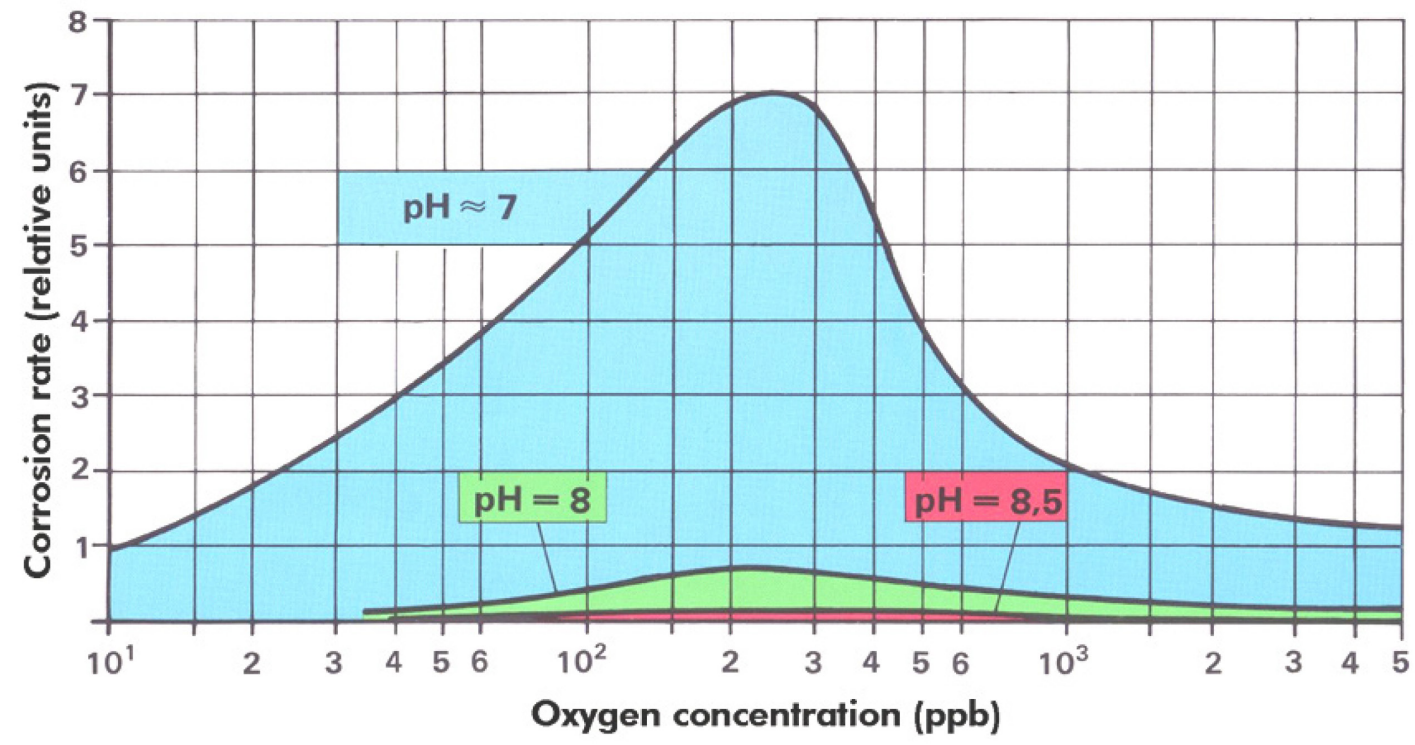

Figure 7. Copper release rate as a function of oxygen concentration and pH. Source: B. Syrett and J. Stein, Prevention of Flow Restrictions in Generator Stator Water Cooling Circuits, EPRI Technical Report. ${ }^{6}$

Figure 8 shows the copper release rate as a function of $\mathrm{pH}$ and oxygen concentration. The colors on the figure show four fields with different copper release rates.

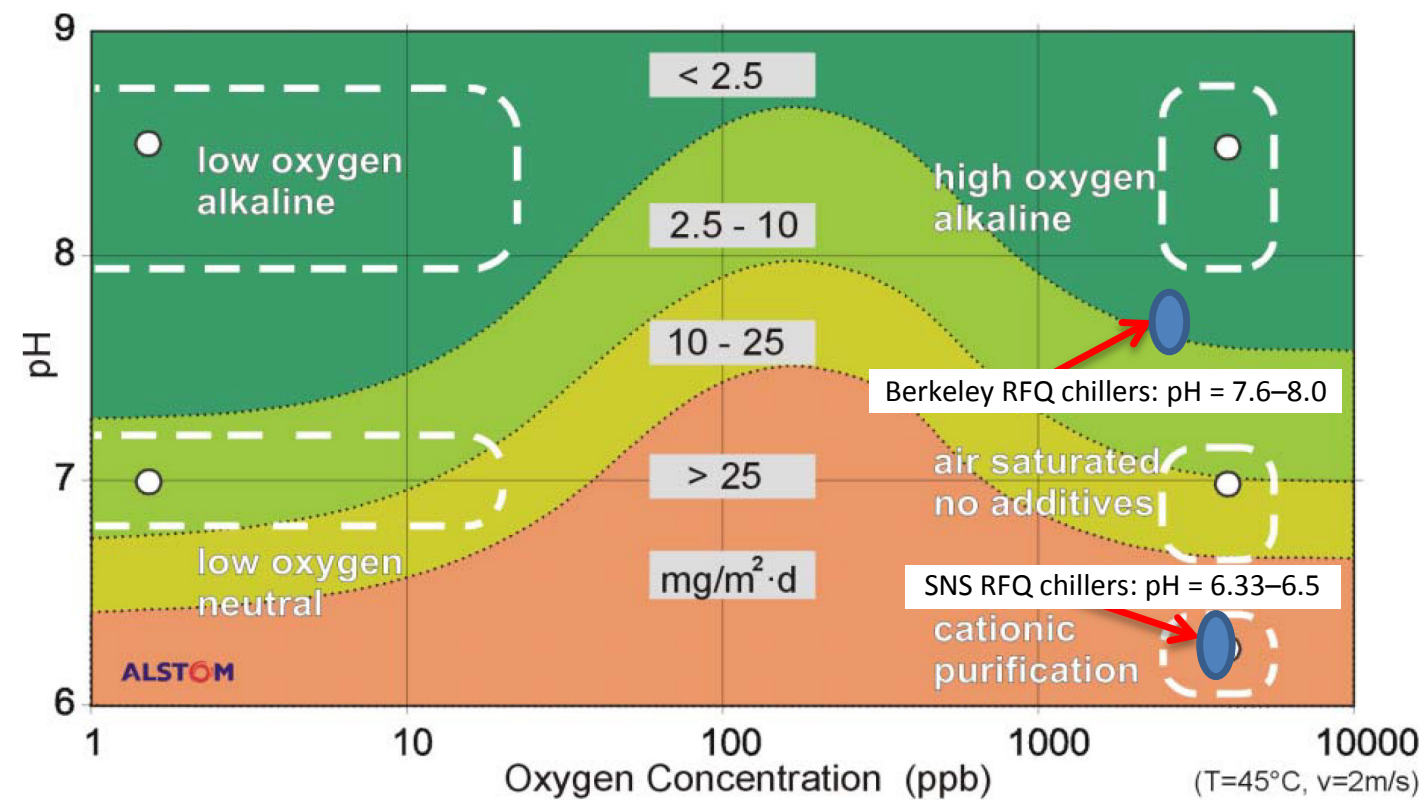

Figure 8. Corrosion rate at various operating regimes. Source: Svoboda Consulting, Review of Cooling Water Chemistry at ORNL/SNS. ${ }^{7}$ 
Figure 8 also shows that five basic operation regimes can be characterized as

- Low-oxygen neutral

- Low-oxygen alkaline

- High-oxygen alkaline

- Air-saturated neutral (with no additives)

- Cationic purification

It can be concluded that the most favorable regimes are in low-oxygen alkaline and high-oxygen alkaline fields, as indicated by the dark green region in Figure 8. The Berkeley RFQ chillers are operating in a high-oxygen region, open to atmosphere, air saturated, and in a mildly alkaline regime at $\mathrm{pH}=7.7-8.0$, as shown in the top right side of the dark green area of Figure 8. The SNS RFQ chillers are operating in high-oxygen region that is slightly acidic at $\mathrm{pH}=6.33-6.5$.

\subsection{CORROSION UNIT CONVERSION}

- $\quad$ Penetration rates (mils per year $=$ mil/year)

- Mass loss ( $\mathrm{g} / \mathrm{m}^{2}$ day, $\mathrm{mg} / \mathrm{m}^{2}$ day)

- Both FE chillers are below the maximum allowed copper corrosion rate maximum of

○ $0.5 \mathrm{mil} /$ year $=309.3 \mathrm{mg} / \mathrm{m}^{2}$ day

○ $25 \mathrm{mg} / \mathrm{m}^{2}$ day $=0.0404 \mathrm{mil} /$ year

\section{CHEMISTRY ANALYSIS SUMMARY}

\subsection{RECENT DATA COLLECTION AND ANALYSIS}

The water conductivity, $\mathrm{pH}$, corrosion inhibitor, copper, iron, and aerobic bacteria content values were collected from the subcontractor's report, which covered two years of data; however, the dissolved oxygen values were collected via instruments mounted on a portable chemistry cart for several weeks only.

\subsection{OBSERVATION FROM CHEMICAL ANALYSIS DATA CHARTS IN APPENDIX A}

- Two years of data with about 100 data points were collected for the Berkeley (FE) RFQ chillers cooling water loop from the subcontractor's reports. ${ }^{8}$ Data collection for the SNS RFQ chiller cooling water loop started in July 2015. At that time there was no regular chemical treatment of the SNS RFQ chiller cooling water loop except for antibacterial chemicals when needed.

- In the last 1.5 years of data collection, the cooling water conductivity (Figure A.1) stabilized in the low hundreds, that is, to about $200 \mathrm{microsiemen} / \mathrm{cm}$ from about $1,000 \mathrm{microsiemen} / \mathrm{cm}$ in an early period of 2015.

- In August 2015 monitoring began for the SNS RFQ at the RFTF but a regular chemical treatment program was not established.

- $\quad$ The pH (Figure A.2) for the Berkeley (FE) RFQ chiller water loop is slightly alkaline, from 7.6 to 8.0, and is fairly consistent. The $\mathrm{pH}$ for the SNS RFQ chiller water loop is slightly acidic, from 6.3 to 6.5 ; however, as the copper content increases the $\mathrm{pH}$ decreases slightly. A $\mathrm{pH}$ under 7.0 is not recommended.

- $\quad$ The Tolyltriazole TT ppm (Figure A.3) stabilized between 7.0 and 8.0 for both, Berkeley (FE) RFQ chiller water loops. An outlier for the vane chiller on February 22, 2016, is considered a data logging error. 
- The copper content (Figure A.4) in the Berkeley (FE) RFQ chiller water loop is stable and under $0.2 \mathrm{ppm}$. The copper content in both SNS RFQ chiller water loops has an upward trend and is higher for the wall chiller, more than $20 \mathrm{ppm}$.

- The iron content (Figure A.5) in the Berkeley (FE) and SNS (spare) RFQ chiller water loops is stable and under $0.2 \mathrm{ppm}$. Most of the SNS Vane and Wall RFQ iron values are zero except for the first data point.

- The aerobic bacteria content (Figure A.6) in the Berkeley (FE) and SNS (spare) RFQ chiller water loops is stable and mostly under 40 cfu except one outlier on May 11, 2015.

Table 2 shows some of the RFQ chemistry result averages for the Berkeley RFQ. Table 3 shows averages for the SNS RFQ.

Table 2. Berkeley (FE) RFQ chemistry data (averaged since November 2014)

\begin{tabular}{|l|c|c|c|}
\hline \multicolumn{1}{|c|}{ Chemistry values } & Vane chiller & Wall chiller & Control range \\
\hline $\mathrm{pH}$ & 8.0 & 7.6 & $7.2-10.5$ \\
\hline Corrosion inhibitor $(\mathrm{ppm})$ & 9.5 & 7.4 & $3-6.4$ \\
\hline Copper $(\mathrm{ppm})$ & 0.14 & 0.19 & $<0.2$ \\
\hline Iron $(\mathrm{ppm})$ & 0.05 & 0.07 & $<0.5$ \\
\hline Aerobic bacteria $(\mathrm{cfu} \min / \mathrm{max})$ & $0 / 100$ & $0 / 60$ & $<100$ \\
\hline Dissolved oxygen $(\mathrm{ppb})$ & 5,471 & 4,125 & Chemical cart data \\
\hline
\end{tabular}

Table 3. SNS (spare) RFQ chemistry data (averaged since August 2015)

\begin{tabular}{|l|c|c|c|}
\hline \multicolumn{1}{|c|}{ Chemistry values } & Vane chiller & Wall chiller & Control range \\
\hline $\mathrm{pH}$ & 6.3 & 6.5 & $7.2-10.5$ \\
\hline Corrosion inhibitor $(\mathrm{ppm})$ & $\mathrm{n} / \mathrm{a}$ & $\mathrm{n} / \mathrm{a}$ & $3-6.4$ \\
\hline Copper $(\mathrm{ppm})$ & 7.2 & 3.8 & $<0.2$ \\
\hline Iron $(\mathrm{ppm})$ & 0.0 & 0.0 & $<0.5$ \\
\hline Aerobic bacteria $(\mathrm{cfu} \min / \mathrm{max})$ & $0 / 20$ & $0 / 25$ & $<100$ \\
\hline Dissolved oxygen $(\mathrm{ppb})$ & 7,833 & $>10,000$ & Chemical cart data \\
\hline
\end{tabular}




\section{CONCLUSION}

\subsection{OBSERVATIONS FROM FIGURE 8, CORROSION RATE AT VARIOUS OPERATING REGIMES}

The Berkeley (FE) chillers have a low copper release rate of $<2.5 \mathrm{mg} / \mathrm{m}^{2}$ day, concluded from RFQ chiller cooling water $\mathrm{pH}$ and oxygen concentration in the water-much lower than in the SNS Water Chemistry Specification requirement described. ${ }^{2}$ The chiller water chemistry regime could be categorized as:

- High oxygen $(>4000 \mathrm{ppb})$

- Favorable $\mathrm{pH}(\mathrm{pH}>7$, alkaline)

$\circ$ Additives used. The corrosion inhibitor is basic, which shifts the chemistry to the alkaline region (see Figure 8, upper right region).

The SNS RFQ (BTF) chillers have a high copper release rate of $>25 \mathrm{mg} / \mathrm{m}^{2}$ day, which does satisfy the SNS Water Chemistry Specification requirements (see the corrosion unit conversion in Section 4.3 and Appendix B). ${ }^{2}$

The SNS RFQ (BTF) chillers water chemistry regime could be categorized as:

- High oxygen

- Unfavorable $\mathrm{pH}(\mathrm{pH}<7$, acidic)

$\circ$ Additives not used. Without a corrosion inhibitor there is no shift to the alkaline region (see Figure 8, lower right region).

\subsection{OBSERVATIONS FROM SNS RFQ PENETRATION RATE CALCULATION}

From the calculation in Appendix B it can be concluded that the SNS RFQ cooling channel average copper penetration rate is approximately $0.03622 \mathrm{mil} /$ year, which is less than the $0.5 \mathrm{mil} /$ year set limit for copper corrosion in SNS Water Chemistry Specification. ${ }^{2}$ The cooling channel area was calculated from SNS Spare RFQ Final Design Review. ${ }^{9}$

By reverse calculation it was found that a $0.5 \mathrm{mil} /$ year copper penetration of cooling channels would give $152 \mathrm{ppb}$, which is far less than the actual $11 \mathrm{ppb}$.

Note: The Berkeley RFQ chilled water loop copper content is typically zero or close to zero ppm; therefore, the cooling channel copper penetration rate should be negligible.

\subsection{CONSIDERATIONS AND OPTIONS}

Favorable corrosion rates are achievable in both the low-oxygen and high-oxygen regions. Rates increase in the mid-oxygen region (especially between 50-600 ppb). Low oxygen concentration is more difficult to achieve and maintain. Considering the installed equipment and available operational techniques, the high-oxygen region is more easily achieved. Both RFQs are currently maintained in the high-oxygen region but differ in $\mathrm{pH}$. Loss of low oxygen control would result in crossing the mid-oxygen region into the high-oxygen region until control was restored and the boundaries were crossed again. Crossing regions is undesirable. Either oxygen condition could be achieved with or without chemical passivation via a corrosion inhibitor.

Without passivation there is a risk for elevated copper concentrations. With passivation there is a risk for unequal passivation. 


\section{RECOMMENDATIONS}

\subsection{RECOMMENDATION FOR BERKELEY RFQ COOLING WATER CHEMISTRY}

Continuation of the current Berkeley (FE) chemistry protocol is the most favorable solution. The advantages are that

- it does not perturb the existing equilibrium and surface condition and

- the tested spare chillers can be placed in service with confidence.

Therefore it is recommended to continue the current chemistry implementation.

\subsection{RECOMMENDATION FOR SNS RFQ COOLING WATER CHEMISTRY}

It is recommended to adopt the current Berkeley RFQ chiller water chemistry protocol for the SNS RFQ chiller cooling water chemistry. The advantage is that this chemistry protocol conforms both RFQ operations, taking advantage of years of operational experience and lessons learned.

\section{FUTURE IMPROVEMENTS}

Currently the actual copper corrosion rate in the RFQ cooling passages is not being measured. In the near future, copper corrosion racks (Figure 9) with three coupons (Figure 10) will be installed for copper corrosion monitoring (in the front end chiller room) for both of the Berkeley RFQ chillers. The installed copper corrosion coupons will be left in the water stream for a period of time and the corrosion rate of the cooling passages calculated relative to the mass loss of the coupons, revealing the actual corrosion rate.
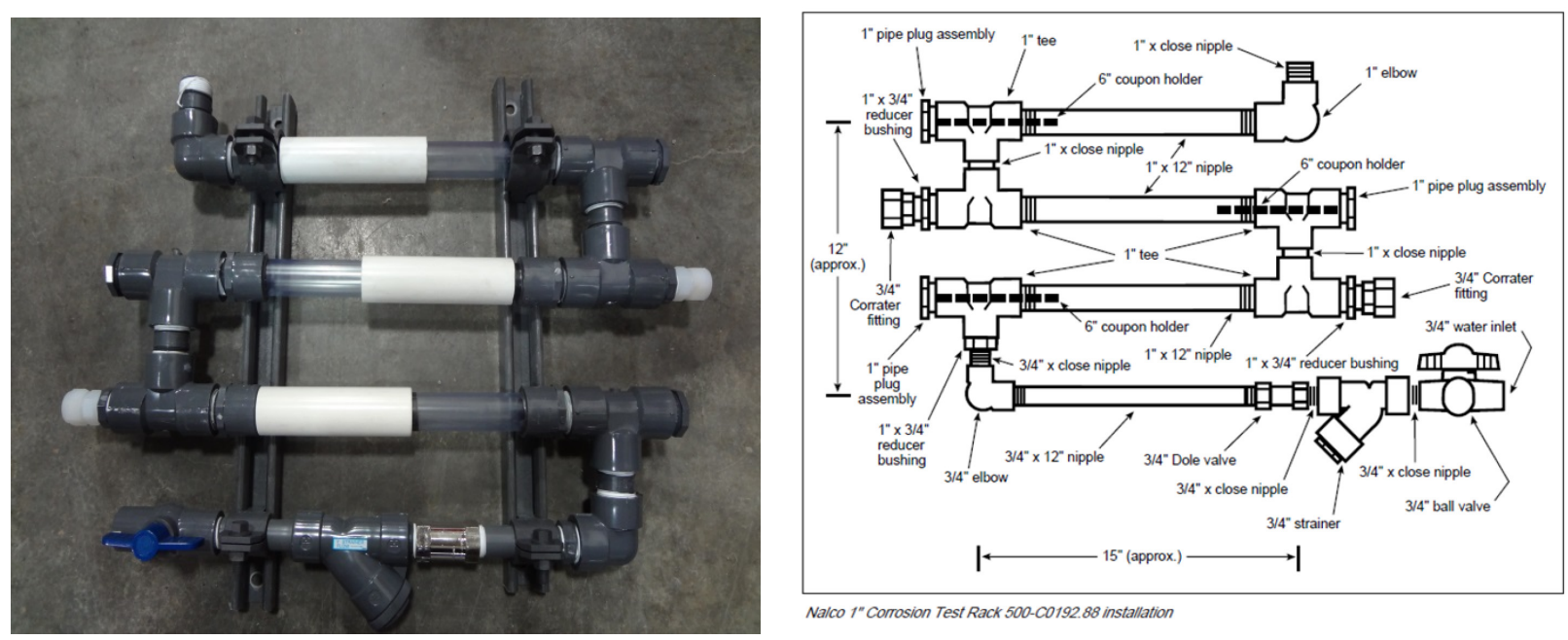

Nalco 1" Corrosion Test Rack 500-C0192.88 installation

Figure 9. Copper corrosion racks. 


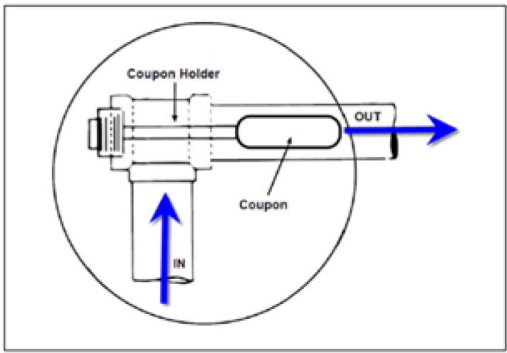

Correct Flow Installation

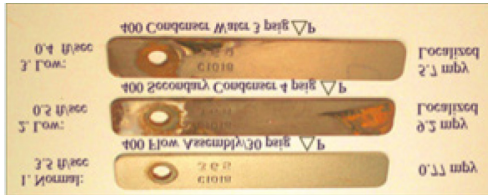

Figure 10. Copper corrosion coupons.

\section{REFERENCES}

1. Steve Virostek and Matt Hoff, RFQ Modules 2, 3, and 4 Preliminary Design Review, Lawrence Berkeley National Laboratory, Berkeley, Calif., 2000.

2. SNS Water Chemistry Specification, SNS-RAD-SR-ADMSSR001 R1, Oak Ridge National Laboratory, Oak Ridge, Tenn., 2012.

3. L. Jacobs, D. Montierth, and J. Schubert, "Cooling Water Systems Serving Copper Technical Components," Review of Accelerator and Commercial Power Industry Applications, June 2009.

4. Primer on Maintaining the Integrity of Water-Cooled Generator Stator Windings, EPRI TR-105504, 12.6-13, 1995. P. H. Effertz and W. Fichte, Beeinflussung der Kupferkorrosion in hochreinem Wasser (Influencing Copper Corrosion in High Purity Water), Jahrbuch Vom Wasser, 1974.

5. B. Syrett and J. Stein, Prevention of Flow Restrictions in Generator Stator Water Cooling Circuits, EPRI Technical Report, 1006684, final report, 2002.

6. Robert Svoboda of Svoboda Consulting, Wettingen, Switzerland, Review of Cooling Water Chemistry at ORNL/SNS, SNS-NFDD-ENG-TR-001-R00, Oak Ridge National Laboratory, Oak Ridge, Tenn., 2010 .

7. Jerry DeFord, enVision ORNL SNS Condenser-Cooling Tower-Chiller-Heating Loops PSR, NALCO Water, an Ecolab Company, 2016.

8. Dr. Christian Piel, SNS Spare RFQ Final Design Review, 3112-BP-8664-0, RI Research Instruments GmbH, Bergisch Gladbach, Germany, 2011. 


\section{APPENDIX A. CHEMICAL ANALYSIS DATA CHARTS FROM NOVEMBER 2014 TO MAY 2016}

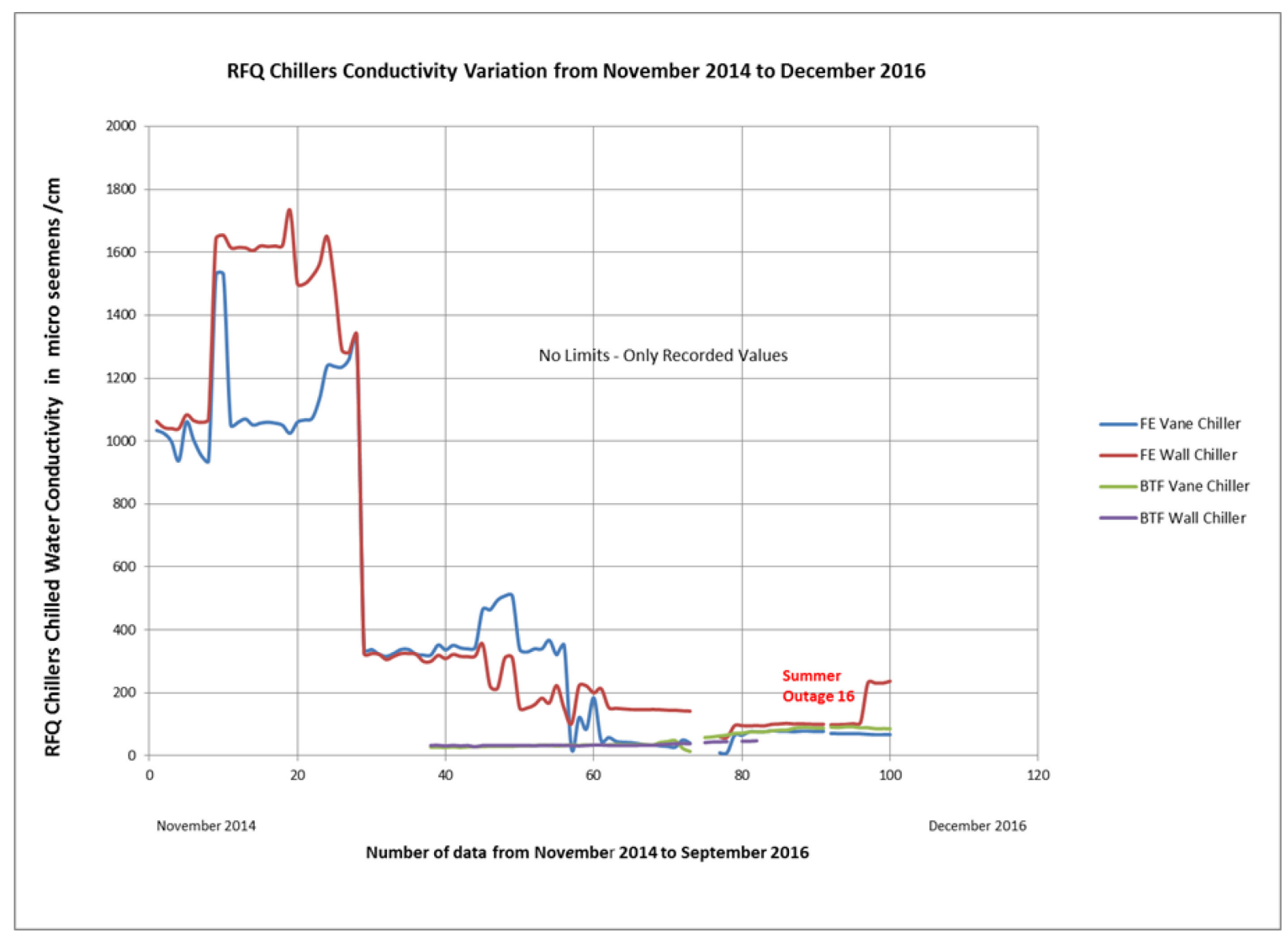

Figure A.1. Chiller conductivity variation from November 2014 to December 2016 for the Berkeley (FE) and SNS (BTF) RFQs. 


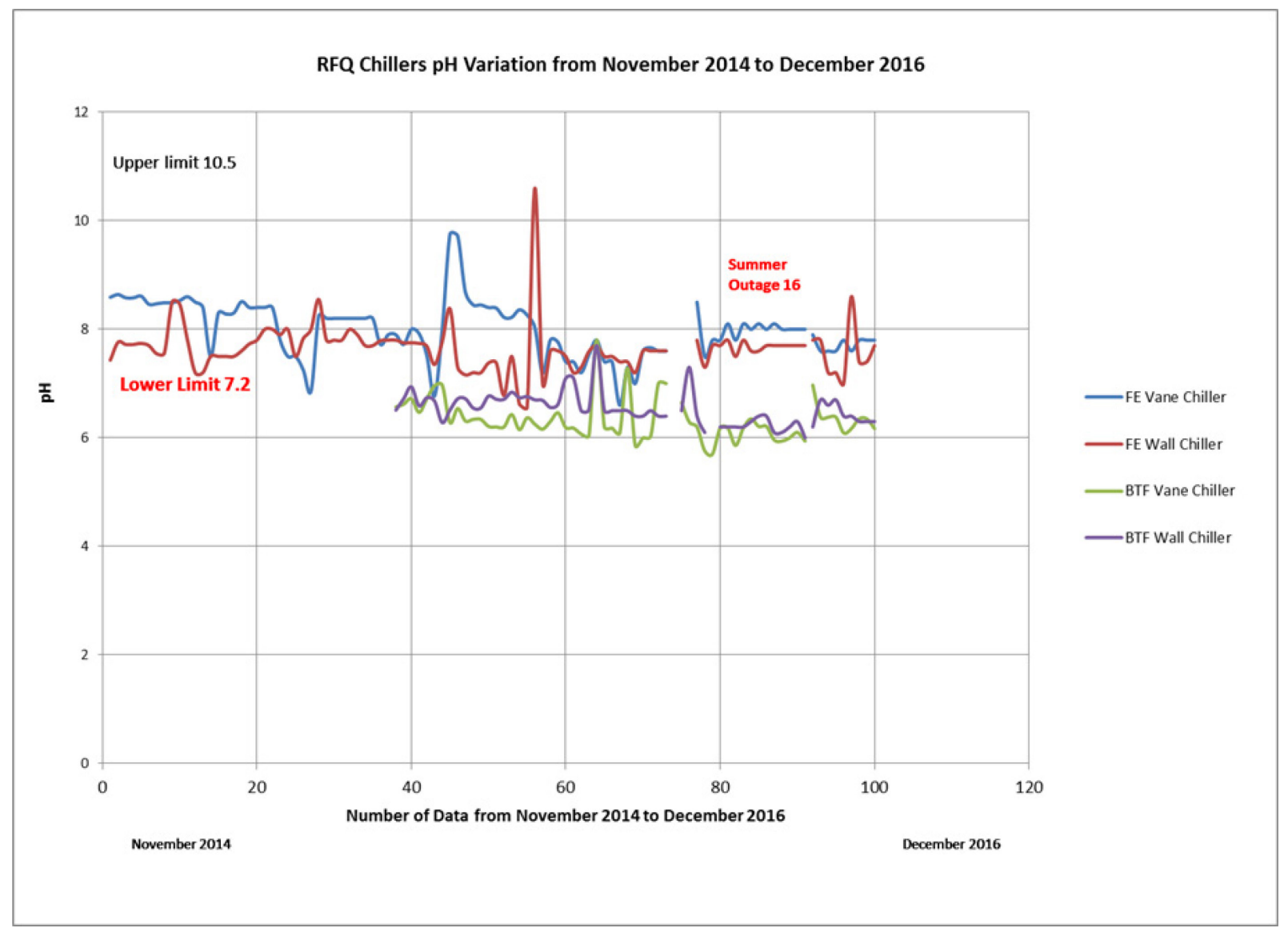

Figure A.2. RFQ chiller pH data variation from November 2014 to December 2016 for the Berkeley (FE) and SNS (BTF) RFQs. 


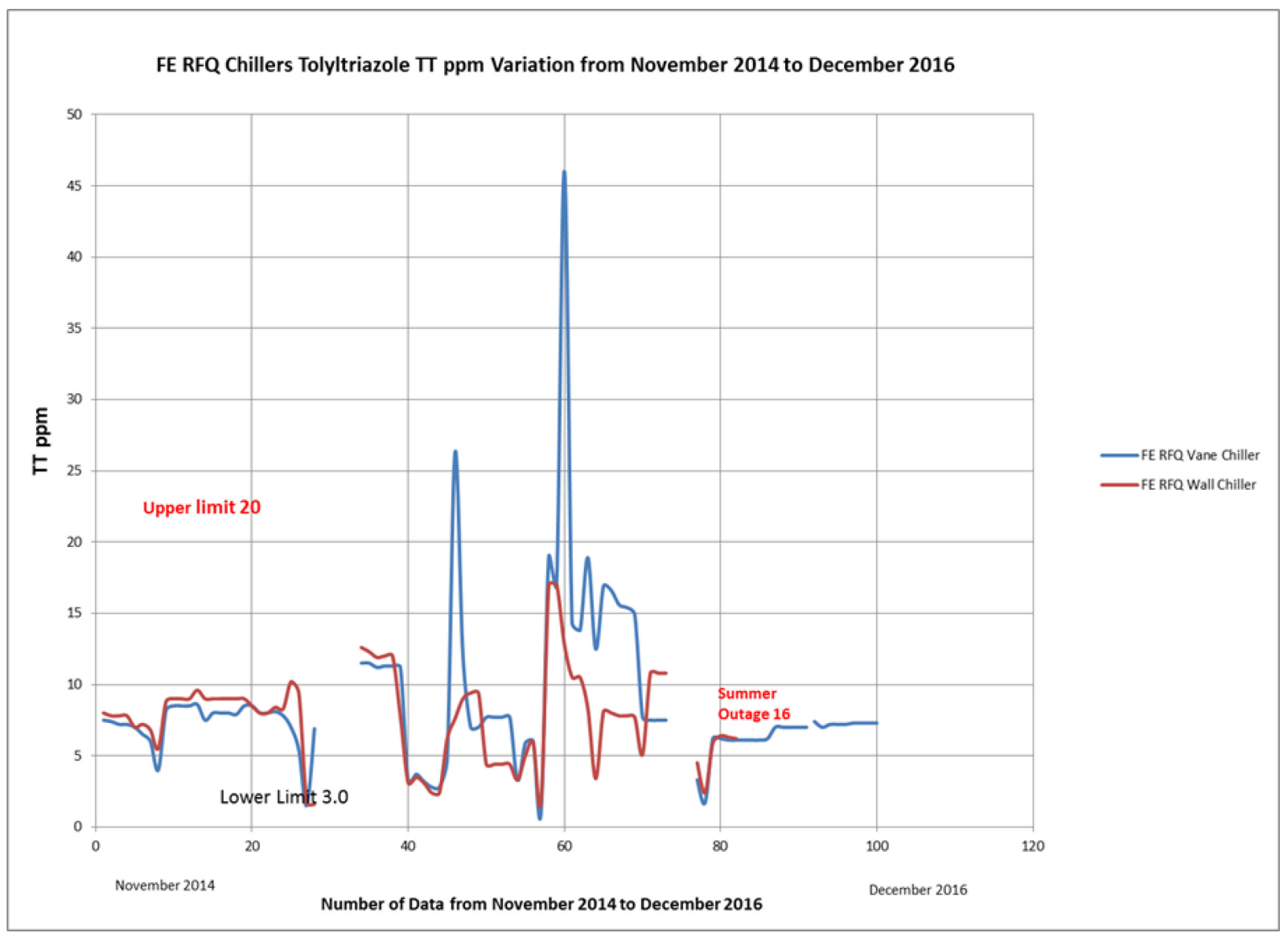

Figure A.3. Tolyltriazole TTppm variation from November 2014 to December 2016 for the Berkeley (FE) RFQ chillers. 


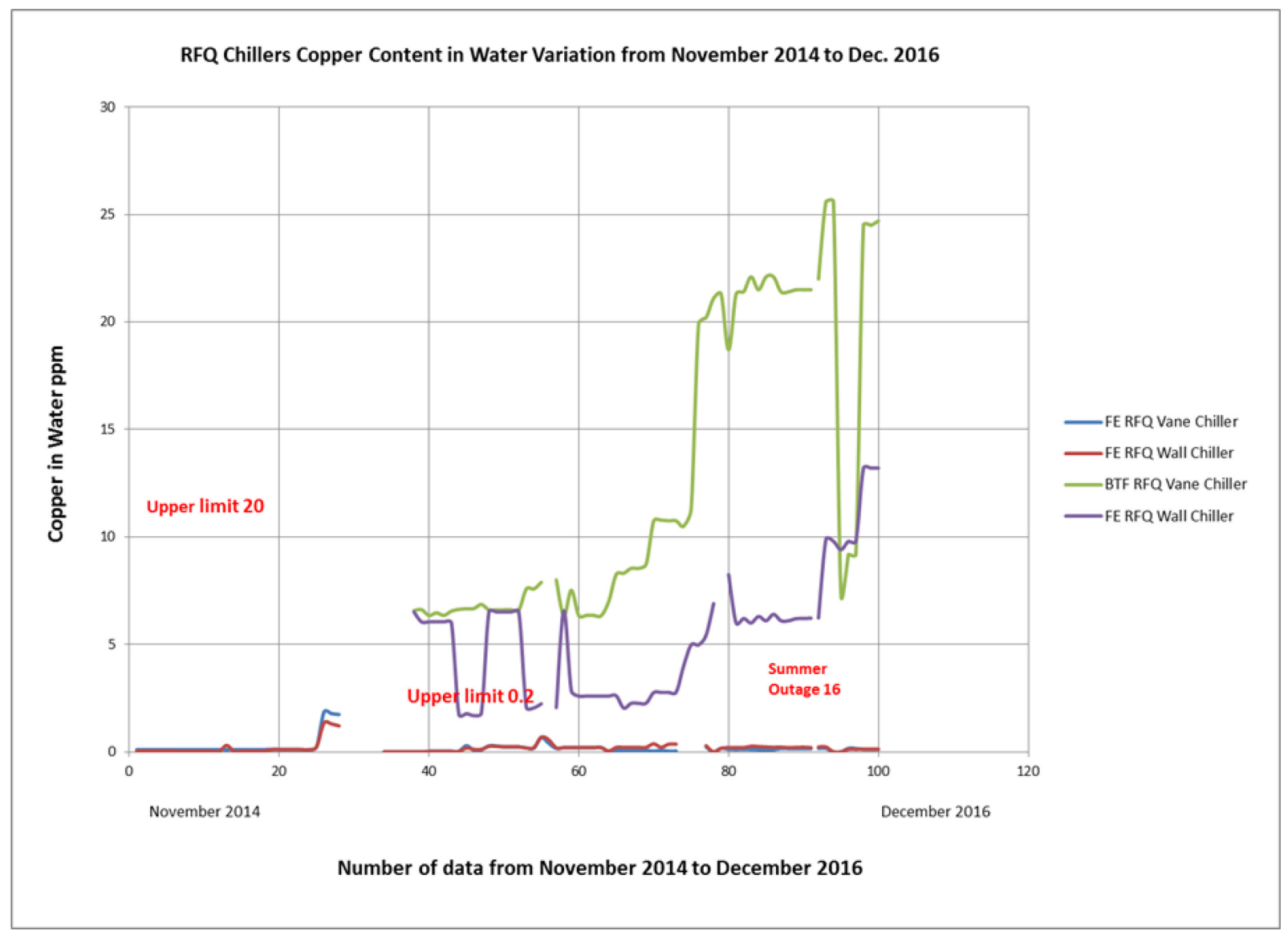

Figure A.4. Copper content in the water variation from November 2014 to December 2016 for the Berkeley (FE) and SNS (BTF) RFQs. 


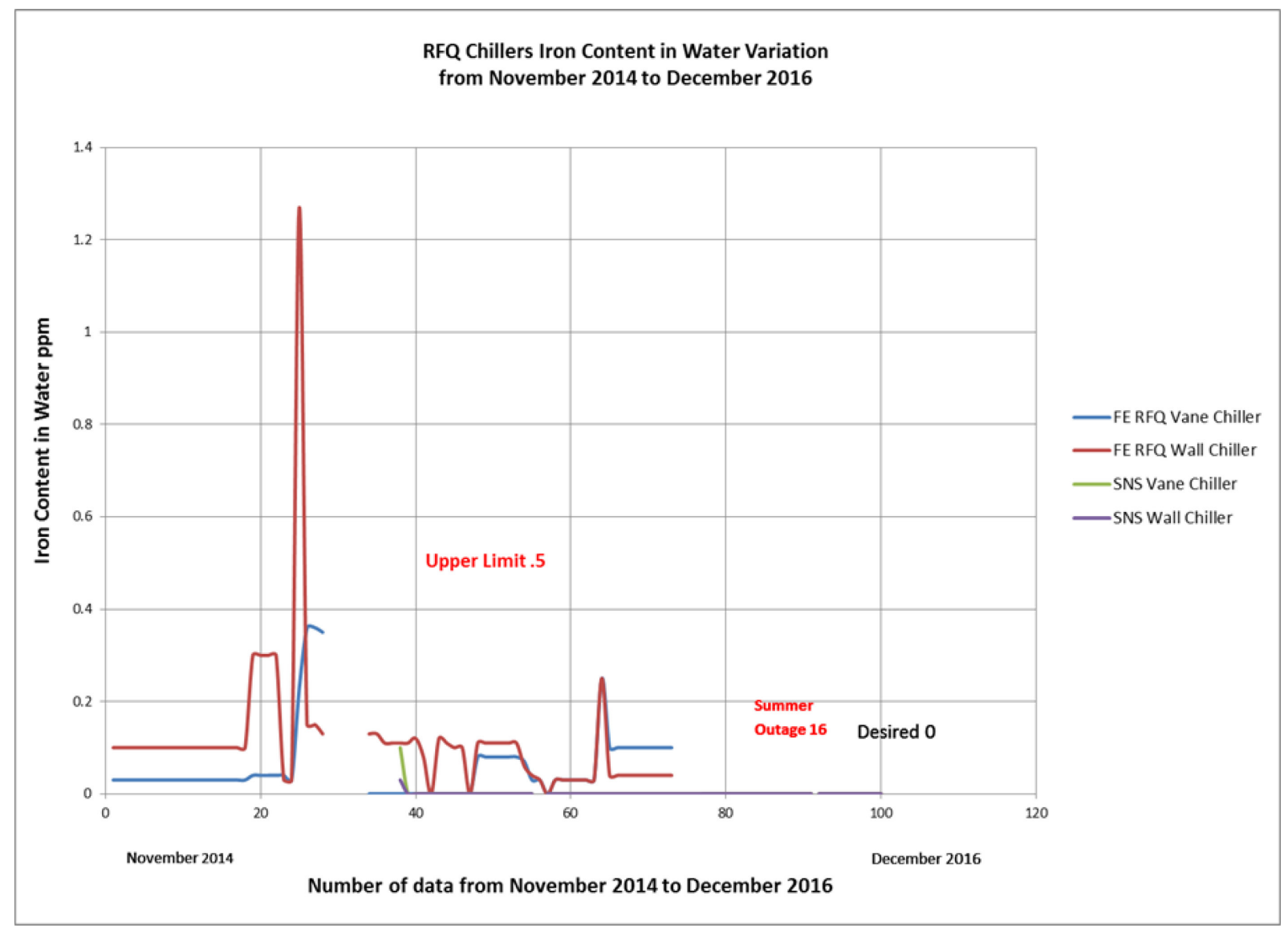

Figure A.5. Iron content in the water variation from November 2014 to December 2016 for the Berkeley (FE) and SNS RFQs. 


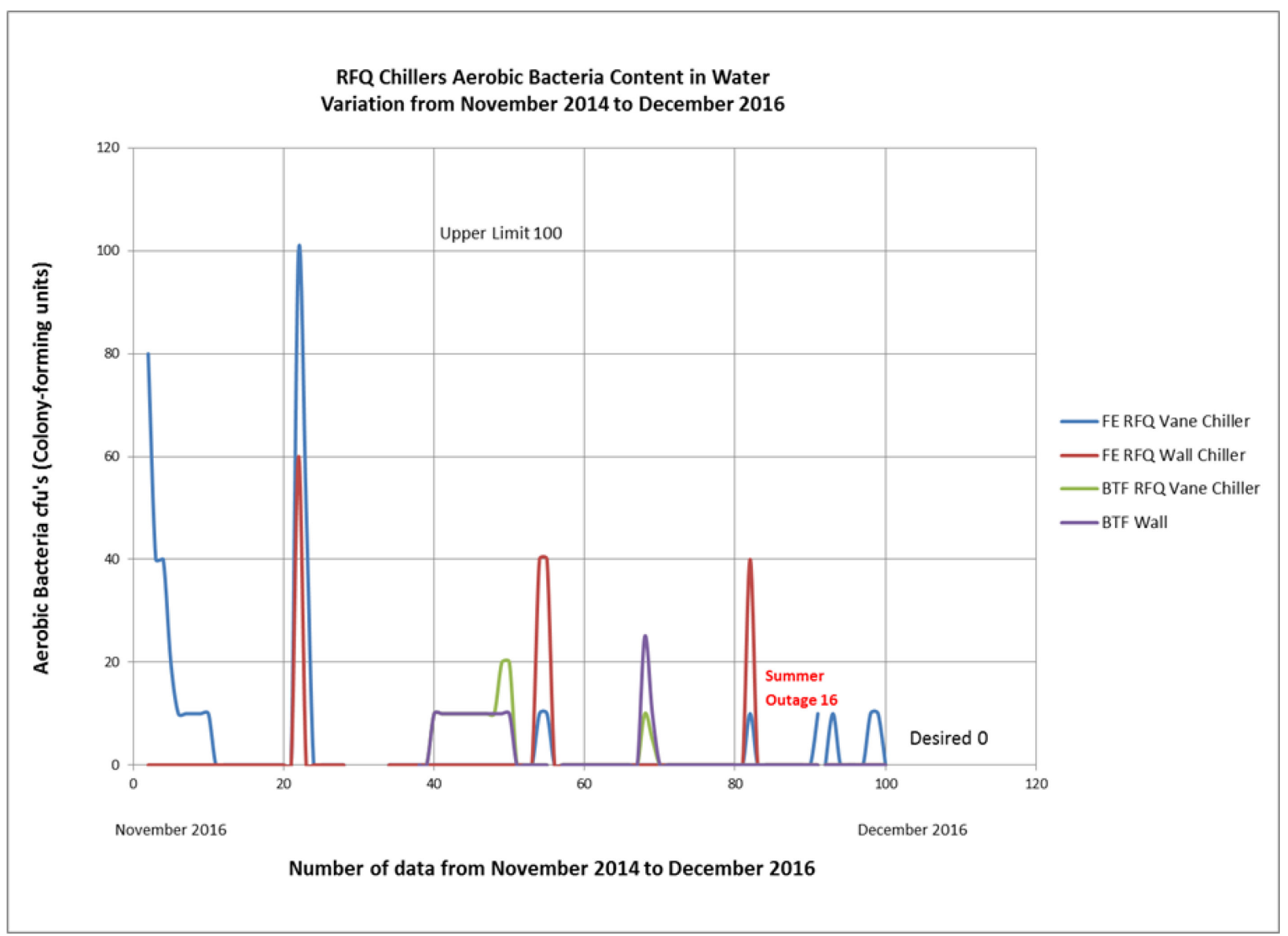

Figure A.6. Aerobic bacteria content in the water variation from November 2014 to December 2016 for the Berkeley (FE) and SNS (BTF) RFQs. 


\section{APPENDIX B. CALCULATION OF COPPER PENETRATION RATE}

Mass loss thickness in a year for a known copper content in the SNS RFQ cooling water given the following:

- The average copper content in the RFQ cooling water accumulated in a year is $11 \mathrm{ppm}=11 \mathrm{~g} / \mathrm{m}^{3}$.

- The cooling channels total surface area from the SNS RFQ manufacturer, RI Research Instruments, added for vane tips, vane base, and end plates, is $\mathrm{A}=1.3404 \mathrm{~m}^{2}$.

- $\quad$ The copper specific gravity $=8.92 \mathrm{~g} / \mathrm{cm}^{2}$.

- The set copper corrosion limit in SNS Water Chemistry Specification $=0.5$ mil/year.

- The time period of consideration of copper corrosion $=1$ year.

Table B.1. SNS RFQ cooling channel copper corrosion calculation table

\begin{tabular}{|l|c|l|l|l|l|l|l|l|l|}
\hline & $\begin{array}{l}\text { Copper } \\
\text { content }\end{array}$ & $\begin{array}{l}\text { Copper Specific } \\
\text { Gravity }\end{array}$ & $\begin{array}{l}\text { Copper } \\
\text { Volume }\end{array}$ & $\begin{array}{l}\text { Cooling channel } \\
\text { Surface area }\end{array}$ & $\begin{array}{l}\text { Cooling channel } \\
\text { Surface area }\end{array}$ & $\begin{array}{l}\text { Copper } \\
\text { Thickness }\end{array}$ & $\begin{array}{l}\text { Copper } \\
\text { Thickness }\end{array}$ & $\begin{array}{l}\text { Copper } \\
\text { Thickness }\end{array}$ & $\begin{array}{l}\text { Copper } \\
\text { Thickness }\end{array}$ \\
\hline $\begin{array}{l}\text { units } \\
\begin{array}{l}\text { Copper } \\
\text { content } \\
\text { increase }\end{array}\end{array}$ & $\mathrm{g}$ & $\mathrm{g} / \mathrm{cm}^{3}$ & $\mathrm{~cm}^{3}$ & $\mathrm{~m}^{2}$ & $\mathrm{~cm}^{2}$ & $\mathrm{~cm}$ & $\mathrm{~mm}$ & micro meters & mils \\
\hline
\end{tabular}

Because $0.03622 \mathrm{mil} /$ year $<0.5 \mathrm{mil} /$ year, the copper penetration rate is less than the set limit.

Reverse calculation is used to determine the copper content (ppb) in cooling water that would result in the copper penetration rate of $0.5 \mathrm{mil} / \mathrm{year}$ in cooling channels.

In the Excel spreadsheet, the copper content was changed until the copper thickness did not become $0.5 \mathrm{mil} /$ year (with iteration).

Table B.2. SNS RFQ cooling channel copper corrosion calculation table

\begin{tabular}{|c|c|c|c|c|c|c|c|c|c|c|c|}
\hline & $\begin{array}{c}\text { Copper } \\
\text { content }\end{array}$ & $\begin{array}{c}\text { Copper Specific } \\
\text { Gravity }\end{array}$ & $\begin{array}{l}\text { Copper } \\
\text { Volume } \\
\end{array}$ & $\begin{array}{c}\text { Cooling channel } \\
\text { Surface area }\end{array}$ & $\begin{array}{c}\text { Cooling channel } \\
\text { Surface area }\end{array}$ & $\begin{array}{c}\text { Calculated } \\
\text { Copper } \\
\text { Thickness }\end{array}$ & $\begin{array}{c}\text { Calculated } \\
\text { Copper } \\
\text { Thickness }\end{array}$ & $\begin{array}{c}\text { Calculated } \\
\text { Copper } \\
\text { Thickness }\end{array}$ & $\begin{array}{c}\text { Calculated } \\
\text { Copper } \\
\text { Thickness }\end{array}$ & Period & $\begin{array}{c}\text { Copper } \\
\text { Thickness in } \\
\text { period }\end{array}$ \\
\hline units & $\mathrm{g}$ & $\mathrm{g} / \mathrm{cm}^{3}$ & $\mathrm{~cm}^{3}$ & $\mathrm{~m}^{2}$ & $\mathrm{~cm}^{2}$ & $\mathrm{~cm}$ & $\mathrm{~mm}$ & micro meters & mils & year & mils \\
\hline $\begin{array}{l}\text { Copper } \\
\text { content } \\
\text { increase }\end{array}$ & 152 & 8.92 & 17.040 & 1.3404 & 13404 & 0.001271289 & 0.01271 & 12.71289 & 0.50051 & 1.00000 & 0.50051 \\
\hline
\end{tabular}





\section{APPENDIX C. NALCO ENVISION REPORT}

Table C.1. Section of Subcontractor Nalco's chemical analysis report.

NALCO Water

An Ecolab Company
ORNL SNS \& CU

3DT Water Treatment Report
3DTRASAR"

Detect Determine Deliver

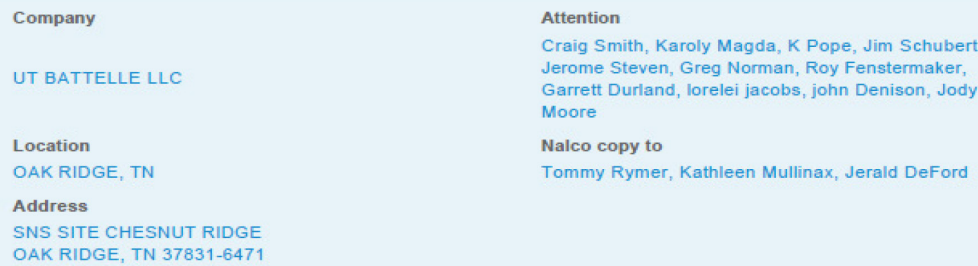

\begin{tabular}{|c|c|c|c|c|}
\hline \multirow{2}{*}{ Closed Loop Wet Tests } & RFQ VANE / 18 KW & RFQ WALL / 25 KW & Target Sensible CW & Control Ranges \\
\hline Conductivity $(\mu \mathrm{S} / \mathrm{cm})$ & 67.1 & 231 & 1359 & Record \\
\hline $\mathrm{pH}$ & 7.8 & 7.4 & 7.9 & $7.2-10.5$ \\
\hline Trasar $(\mathrm{ppm})$ & & & 2509 & $2000-6000$ \\
\hline
\end{tabular}

\begin{tabular}{|c|c|c|c|c|}
\hline $\mathrm{MoO}_{4}(\mathrm{ppm})$ & & & 139.0 & $75-150$ \\
\hline Tolyltriazole (T ppm) & 7.3 & 7.3 & 8.5 & $3.0-6.4$ \\
\hline Copper (ppm) & 0.12 & 0.13 & 0.08 & $<0.2$ \\
\hline Iron (Fe2) & 0 & 0 & 0.21 & $<.5$ \\
\hline Aerobic Bacteria (cfu's) & 10 & 0 & 0 & 0 \\
\hline Anaerobic Bacteria (cfu's) & 0 & 0 & 0 & 0 \\
\hline
\end{tabular}

\section{Closed Loop Wet Tests}

\begin{tabular}{c|c|c|c|c|}
\cline { 2 - 4 } & BTF Vane & BTF Wall & & Control Ranges \\
\hline Conductivity $(\mu \mathrm{S} / \mathrm{cm})$ & 86.2 & 66.3 & & Record \\
\hline $\mathrm{pH}$ & 6.35 & 6.3 & & $2000-6000$ \\
\hline Trasar $(\mathrm{ppm})$ & & & & $75-150$ \\
\hline $\mathrm{MoO}_{4}(\mathrm{ppm})$ & & & & $3.0-6.4$ \\
\hline Tolyltriazole (T) ppm) & & & & $<0.2$ \\
\hline Copper (ppm) & 24.5 & 13.20 & $<.5$ \\
\hline Iron (Fe2) & 0 & 0 & & $<100$ \\
\hline Aerobic Bacteria (cfu's) & 0 & 0 & & 0 \\
\hline Anaerobic Bacteria (cfu's) & 0 & & & \\
\hline
\end{tabular}

18 RFQ VANE Chiller - B (Blgd 8100)

The Vane chiller is within all control ranges. No changes needed. Microbial is zero.

25 RFQ WALL Chiller - A (BIdg 8100)

The Wall chiller is just within all control ranges. No changes needed. Microbial is zero.

BTF 18 KW Vane Chiller

The BTF Vane chiller system copper in the system is up to $24.5 \mathrm{ppm}$ and the $\mathrm{pH}$ is 6.35 . Microbial is zero

BTF $25 \mathrm{KW}$ Wall Chiller

The BTF Wall system copper is 13.2 and the $\mathrm{pH}$ is 6.3. Microbial is zero

Target Sensible Chilled Water

The target system 3DT unit is in range in all areas. Replaced the $\mathrm{pH}$ probe today as the probe was not responding to $\mathrm{pH}$ changes. No other changes are needed at this time. 
